
doi: https://doi.org/10.33369/jik.v5i2.14514

\title{
PENERAPAN MODEL PEMBELAJARAN QUANTUM UNTUK MENINGKATKAN KEMAMPUAN MENULIS TEKS PERSUASIF SISWA KELAS VIII A SMP NEGERI 46 BENGKULU UTARA
}

\author{
${ }^{1}$ Else Pebrinda, ${ }^{2} \mathrm{M}$. Arifin, ${ }^{3}$ Ria Ariesta \\ 1,2,3 Program Studi Pendidikan Bahasa Indonesia FKIP Universitas Bengkulu
}

Abstrak

\section{Korespondensi: febrindaelse@gmail.com}

Tujuan penelitian ini ialah (1) mengetahui proses penerapan model pembelajaran quantum saat dilaksanakannya pembelajaran teks persuasif di kelas VIII A SMP Negeri 46 Bengkulu Utara, dan (2) mengetahui hasil belajar siswa terhadap penerapan model pembelajaran quantum saat proses pembelajaran menulis teks persuasif. Penelitian ini adalah penelitian tindakan kelas (PTK). Prosedur Penelitian ini dibagi atas empat komponen yaitu refleksi, perencanaan, observasi, dan tindakan. Subjek penelitian ini adalah guru dan siswa. Instumen penelitian terdiri atas instrumen tes dan nontes. Teknik analisis data dilakukan dengan analisis kualitatif dan kuantitatif. Sintaks penerapan model pembelajaran quantum dalam penelitian ini ialah (1) tumbuhkan, (2) alami, (3) namai, (4) demonstrasi, (5) ulangi, dan (6) rayakan. Hasil penelitian menunjukkan bahwa penerapan model pembelajaran quantum dapat meningkatkan hasil belajar siswa khususnya kemampuan menulis teks persuasif siswa, karena tiap tahapan hasil belajar (menulis) siswa meningkat secara siginfikan, tahap siklus I memperoleh nilai 67,3 dan jumlah siswa yang tuntas 6 siswa dengan persentase 54,54\%, dan siklus II memperoleh nilai 77,13 dan seluruh siswa tuntas dengan persentase $100 \%$.

Kata Kunci: Quantum, Menulis, Persuasif

\section{Abstract}

The objectives of this study were (1) to find out the process of implementing the quantum learning model during the implementation of persuasive text learning in class VIII A SMP Negeri 46 Bengkulu Utara, and (2) to find out the student learning outcomes regarding the application of the quantum learning model during the learning process of writing persuasive text. This research is a classroom action research (PTK). This research procedure is divided into four components, namely reflection, planning, observation, and action. The subjects of this study were teachers and students. The research instrument consisted of test and non-test instruments. The data were analyzed by using qualitative and quantitative analysis. The syntax for implementing the quantum learning model in this study is (1) grow, (2) natural, (3) name, (4) demonstration, (5) repeat, and (6) celebrate. The results showed that the application of the quantum learning model can improve student learning outcomes, especially the ability to write persuasive text of students, because each stage of student learning outcomes (writing) increased significantly, the first cycle stage obtained a value of 67.3 and the number of students who completed 6 students with a percentage $54.54 \%$, and the second cycle got a value of 77.13 and all students completed with a percentage of $100 \%$.

Keywords: Quantum, Writing, Persuasive 


\section{PENDAHULUAN}

Pembelajaran merupakan suatu upaya yang dilakukan guru dalam kegiatan belajar di suatu instansi untuk mencapai tujuan pembelajaran. Tercapainya suatu tujuan pembelajaran tidak terlepas dari peran guru, pengelolaan kelas yang baik, dan pembelajaran yang menyenangkan bagi siswa. Zain (2014:174) mengemukakan pengelolaan kelas yang optimal akan melahirkan interaksi belajar mengajar yang baik sehingga hasil pembelajaran dapat tercapai sepenuhnya. Selain itu, Porter dalam Kosasih (2014: 114) berpendapat bahwa syarat pembelajaran yang efektif adalah lingkungan yang mendukung dan menyenangkan.

Tujuan Kurikulum 2013 mengisyaratkan bahwa pembelajaran bahasa Indonesia diharapkan mampu menghasilkan siswa yang memiliki keterampilan, sikap yang baik, dan pengetahuan yang lebih baik. Pembelajaran bahasa Indonesia dalam kurikulum 2013 berorientasi pada teks. Ahmadi dalam Arifina (2015: 111-112) menyatakan bahasa Indonesia merupakan salah satu mata pelajaran pokok di sekolah. Salah satu aspek keterampilan berbahasa adalah menulis.

Menulis adalah kegiatan memikirkan, menggali, dan mengembangkan ide, dan menuangkannya dalam bentuk tulisan yang diperoleh dari proses menyimak dan membaca, kemudian dapat diungkapkan secara lisan. Teks persuasif adalah suatu teks yang bersifat membujuk, mengajak, ataupun menyuruh pembaca untuk melakukan sesuatu sesuai dengan apa yang disampaikan penulis. Menurut Dalman dalam Arifah (2015:2) Menulis teks persuasif adalah suatu kegiatan yang berbentuk tulisan yang bertujuan untuk mengajak serta mempengaruhi pembaca. Salah satu Kompetensi Dasar (KD) yang terdapat dalam mata pelajaran bahasa Indonesia di kelas VIII sebagai berikut:

3.14 Menelaah struktur dan kebahasaan teks persuasif yang berupa saran, ajakan, dan pertimbangan tentang berbagai permasalahan aktual (lingkungan hidup, kondisi sosial, keragaman sosial, dan sebagainya) yang didengar dan dibaca.

4.14 Menyajikan teks persuasi (saran, ajakan, dan pertimbangan) secara tulis dan lisan dengan memperhatikan struktur, kebahasaan, atau aspek lisan.

Berdasarkan data yang diperoleh dari salah satu Guru Mata Pelajaran Bahasa Indonesia di SMP Negeri 46 Bengkulu Utara, nilai rata-rata menulis siswa belum mencapai Kriteria Ketuntasan Minimal (KKM) yaitu berkisar 70\%, sedangkan nilai KKM pelajaran bahasa Indonesia di SMP Negeri 46 Bengkulu Utara khususnya pada kelas VIII adalah $75 \%$.

Kosasih (2018: 119-120) menyatakan salah satu permasalahan yang sering ditemukan dalam dunia pendidikan di Indonesia adalah proses pembelajaran yang hanya mengemukakan konsep-konsep, metode pembelajaran yang pada umumnya berlangsung secara deduktif (pembelajaran satu arah). Strategi pembelajaran itu dianggap kurang mengeskplorasi wawasan sikap, pengetahuan, dan keterampilan siswa. Metode deduktif, menjadikan potensi siswa tidak berkembang secara optimal. Siswa tidak memiliki banyak kesempatan untuk berekspresi dan berkreasi, dan hasil pembelajaran menjadi kurang bermakna.

Model pembelajaran quantum adalah strategi yang efektif dalam pengelolaan kelas karena guru dapat menggunakan berbagai macam gaya belajar sehingga membuat suasana pembelajaran menjadi meriah dan menyenangkan. Model pembelajaran quantum adalah rancangan pembelajaran yang dipertama kali diperkenalkan oleh DePorter pada 
tahun 1982, Kosasih (2018: 114) mengemukakan konsep pembelajaran quantum ialah membuat siswa senang belajar jauh lebih penting daripada menuntut siswa mau belajar agar menjadi juara atau mencapai presetasi tertentu. Menurut Porter (2011) quantum learning adalah kiat, petunjuk, strategi, dan seluruh proses belajar yang dapat mempertajam pemahaman dan daya ingat serta membuat belajar sebagai suatu proses yang menyenangkan dan bermanfaat. Kurniawan (2015: 1) menyatakan pembelajaran quantum dapat dikatakan sebagai model pembelajaran yang menekankan untuk memberikan manfaat yang bermakna dan juga menekankan pada tingkat kesenangan dari peserta didik atau siswa.

Berdasarkan hasil observasi penulis pada salah satu guru Mata Pelajaran Bahasa Indonesia dan siswa kelas VIII A SMP Negeri 46 Bengkulu Utara yang dilaksanakan pada beberapa waktu yang lalu, penulis melakukan wawancara dan mengamati langsung proses pembelajaran di kelas tentang kendala yang dihadapi guru dan siswa dalam proses pembelajaran bahasa Indonesia. Kendala tersebut yakni : (1) dari awal hingga pembelajaran berakhir siswa malas mengembangkan imajinasi dan saat proses pembelajaran siswa cenderung mengandal temannya saja, (2) kurangnya perhatian siswa dalam proses pembelajaran, (3) pada saat pembelajaran dimulai hingga pembelajaran berakhir kondisi kelas tidak kondusif, dan (4) kurangnya minat belajar siswa dapat dilihat dari kurangnya persiapan saat memulai pelajaran dan kurangnya respon yang diberikan siswa. Namun, masalah yang ditemukan tidak terlepas dari peran guru dalam pengelolaan kelas, pada saat pembelajaran guru memang memberi kesempatan bagi semua siswa untuk berbicara atau mengungkapkan argumen, tetapi guru tidak memberikan penguatan dan pengakuan baik berupa verbal maupun nonverbal kepada siswa yang menanggapi materi (menjawab, menanya, menggapi, dan menambahkan). Selain itu, guru tidak mampu menarik perhatian siswa dalam proses pembelajaran sehingga pada saat pembelajaran siswa terlihat mengantuk. Kedua hal tersebut membuat hasil pembelajaran siswa menjadi tidak maksimal.

Penelitian yang relevan dengan penelitian ini adalah (Nur Laili Badriyah, 2020) dengan judul Pengarub Penggunaan Model Mind Mapping Berbasis Quantum Learning Terbadap Keterampilan Menulis Teks Persuasi SIswa Kelas VIII MTs. Masybudiyah Giri Kebomas Gresik. Selain itu, penelitian (Indah Ayu Irwina Silalahi, 2018) dengan judul Menerapkan Model Pembelajaran Quantum Teaching untuk. Meningkatkan Hasil Belajar Siswa Dalam Keterampilan Menulis Karangan Narasi di Kelas V SD Dharma Wanita Pertiwi Medan Tahun Pembelajaran 2017/2018. Berdasarkan kajian empiris, hasil penelitian menunjukkan bahwa model pembelajaran quantum merupakan model pembelajaran yang dapat meningkatkan hasil pembelajaran. Model pembelajaran quantum memberi keterampilan guru dalam mengelola kelas sehingga terjadinya peningkatan partisispasi siswa dalam proses pembelajaran, meningkatkan kemampuan menulis siswa khususnya pada teks persuasif.

Tujuan dari atrikel ini untuk mengetahui proses penerapan model pembelajaran quantum saat dilaksanakannya pembelajaran teks persuasif di kelas VIII A SMP Negeri 46 Bengkulu Utara dan mengetahui hasil belajar siswa terhadap penerapan model pembelajaran quantum saat proses pembelajaran menulis teks persuasif. permasalahan dalam penelitian ini yaitu bagaimana proses penerapan model pembelajaran quantum pada pembelajaran menulis teks persuasif di kelas VIII A SMP Negeri 46 Bengkulu Utara dan bagaimana hasil belajar siswa terhadap penerapan model pembelajaran quantum khususnya menulis teks persuasif. pemecahan masalah pada penelitian ini yaitu 
tumbuhkan, alami, namai, demonstrasi, ulangi, dan rayakan. Penelitian ini juga memiliki manfaat, yaitu manfaat teoritis dan manfaat praktis.

\section{METODE}

Rancangan penelitian ini adalah penelitian tindak kelas. Penelitian ini dilakukan oleh guru sebagai upaya pemecahan masalah dan peningkatan mutu pembelajaran di sekolah dengan tujuan memperbaiki kinerjanya sehingga dapat meningkatkan hasil belajar (menulis) siswa dengan menerapkan model pembelajaran quantum pada saat pembelajaran. prosedur penelitian tindak kelas ini adaptasi dari Model Kemmis dan Mc Taggart yang terbagi atas empat komponen yaitu refleksi, perencanaan, observasi, dan tindakan.

Penelitian dilaksanakan di SMP Negeri 46 Bengkulu Utara yang beralamat di jalan Desa Padang Bendar Kecamatan Hulu Palik Kabupaten Bengkulu Utara Kode Pos 38374 Provinsi Bengkulu, khususnya di kelas VIII A SMP Negeri 46 Bengkulu Utara dengan jumlah 11 responden. Penelitian dilakukan pada tanggal 14 s/d 18 Agustus 2020. Selama 2 siklus yang terdiri atas 4 kali pertemuan.

Instrumen penelitian ini terdiri dari instumen tes dan instrumen nontes. Instumen tes ini menjadi tolak ukur penulis dalam mengumpul dan mengalisis data. Tes yang digunakan ialah menulis teks persuasif. hasil tes tersebut berpacu pada indikator keberhasilan penelitian. Penelitian ini menggunakan acuan nilai berskala 9. Skala tersebut adalah skala yang ada pada tempat penelitian yakni SMP Negeri 46 Bengkulu Utara. Konversi penilaian tersebut ada 4 (empat) kategori yaitu sangat baik, baik, cukup, dan kurang. Konversi penilaian yang digunakan merupakan modifikasi dari Kemendikbud (2013:131). Tes yang digunakan dalam penilitian ini ialah menulis teks persuasif, ada 6 aspek yang dinilai yaitu 1) pengenalan isu, 2) rangkaian argumen, 3) pernyataan ajakan/imbauan, 4) penegasan kembali, 5) kalimat, dan 6) EYD dan tanda baca.

Instrumen nontes penelitian ini ialah lembar observasi dan dokumentasi. Observasi dalam penelitian ini ialah pengamatan dan pencatatan mengenai proses pembelajaran menulis teks persuasif yang berlangsung dengan menerapkan model pembelajaran quantum. Sedangkan dokumentasi dalam penelitian ini berupa lembar hasil menulis teks persuasif siswa jelas VIII A SMP Negeri 46 Bengkulu Utara. Berhubungan dengan penyebaran virus corona atau Covid-19 (Corona Virus Disease) yang sedang hidapi, maka hal tersebut menyebabkan terbatasnya aktivitas manusia dalam melakukan aktivitas sehari-hari. Banyak yang berdampak pada penyebaran virus corona, salah satunya ialah dunia pendidikan. SMP Negeri 46 Bengkulu Utara merupakan salah satu sekolah yang masih menerapkan kegiatan belajar mengajar secara tatap muka dengan syarat mengunakan atribut kesehatan serta membatasi siswa dalam proses belajar secara tatap muka yaitu dengan membagi jadwal masuk sekolah. Berkenaan dengan hal tersebut, Tindakan penelitian yang dilakukan penulis berkolaborasi dengan guru mata pelajaran bahasa Indonesia ialah sebagai berikut:

1. Memposisikan meja dan kursi siswa dengan jarak 1 meter.

2. Sebelum masuk kelas, siswa diminta untuk mencuci tangan terlebih dahulu.

3. Memberikan materi teks persuasif kepada siswa

4. Setelah langkah ketiga dilaksanakan, maka langkah selanjutnya ialah memberikan penjelasan kepada siswa mengenai materi teks persuasif. 


\section{Else Pebrinda, M. Arifin, Ria Ariesta}

5. Setelah langkah ketiga dan keempat dilaksanakan, maka langkah terakhir ialah memberikan tugas kepada siswa berupa tugas membuat (menulis) teks persuasif.

Teknik analisis data penelitian ini dilakukan dengan teknik analisis kualitatif dan teknik analisis kuantitatif. Teknik analisis kualitatif bertujuan untuk mendeskripsikan proses penerapan model pembelajaran quantum yang dilaksanakan saat pembelajaran menulis teks persuasif. data penelitian yang diambil dan dilakukan dengan cara mengamati proses pembelajaran dalam menerapakn model pembelajaran quantum dalam proses pembelajaran dengan menerapakan langkah TANDUR (Tumbuhkan, alami, namai, demonstrasi, ulangi, dan rayakan). Tahap-tahap analisis data adaptasi dari model Miles dan Huberman (Huberman, 2011) yaitu mulai dari tahap reduksi data, analisis data, hingga penarikan kesimpulan. Sedangkan teknik analisis kuantitatif bertujuan untuk menganalisis nilai tes menulis teks persuasif dengan merapkan model pembelajaran quantum, hal tersebut dilakukan untuk menggambarkan keberhasilan pembelajaran. analisis data kuantitatif tersebut dapat dihitung dengan menggunakan rumus berikut:

$$
N P=\frac{N K}{R} \times 100
$$

Keterangan:

$$
\begin{aligned}
& \mathrm{NP}=\text { Nilai persentase menulis teks persuasif } \\
& \mathrm{NK}=\text { Nilai Kumulatif (Keseluruhan) } \\
& \mathrm{R}=\text { Jumlah Responden }
\end{aligned}
$$

Kriteria keberhasilan pada penelitian ini ialah sebagai berikut:

1. Penelitian ini dikatakan berhasil apabila guru sudah berhasil menerapkan model pembelajaran quantum dalam proses pembelajaran sesuai dengan langkah-langkah pembelajaran pada rencana pelaksanaan pembelajaran (RPP).

2. penelitian ini dikatakan berhasil apabila setelah diterapkan model pembelajaran quantum dalam proses pembelajaran hasil belajar (menulis) teks persuasif siswa mencapai indikator keberhasilan yaitu 75 .

\section{HASIL DAN PEMBAHASAN}

\section{Hasil}

Berdasarkan hasil pengamatan, model pembelajaran quantum memberi dampak positif terhadap hasil belajar siswa khususnya menulis teks persuasif. Hasil belajar (menulis) teks persuasif siswa menunjukkan terjadinya peningkatan secara signifikan setelah diberi tindakan. Penelitian ini dihentikan pada siklus II karena seluruh aspek penilaian yang dilakukan telah mencapai hasil yang maksimal.

\section{Penerapan model pembelajaran quantum dalam pembelajaran menulis teks persuasif}

Pelaksanaan siklus I dan siklus II bertujuan untuk mengambarkan proses pembelajaran dalam menerapkan model pembelajaran quantum dan mengambarkan hasil belajar (menulis) siswa pada materi teks persuasif. Adapun pelaksanaan pembelajaran dalam menerapkan model pembelajaran quantum pada pembelajaran menulis teks persuasif yakni sebagai berikut.

\section{Siklus I}


1) Tumbubkan, dalam penerapan tumbuhkan "pada saat memulai pembahasan materi, guru melakukan kegiatan tanya jawab kepada siswa tentang materi teks persuasif'. Penerapan tumbuhkan memberi perubahan terhadap proses pembelajaran karena dalam proses pembelajaran kali ini antusias siswa dalam mengikuti proses pembelajaran sudah mulai meningkat dibanding dengan proses pembelajaran sebelumnya, biasanya dalam proses pembelajaran guru jarang mendapat respon dari siswa. Namun aspek tumbubkan yang dilakukan oleh guru pada pembelajaran siklus I hanya dilakukan pada kegiatan pembuka saja, seharusnya aspek ini juga bisa dilakukan pada kegiatan inti.

2) Alami, dalam penerapan aspek ini guru meminta siswa menyebutkan salah satu contoh iklan yang diketahui oleh siswa. Kemudian guru mengajukan pertanyaan kepada siswa, setelah itu siswa tersebut menjadi diam karena masih malu-malu dan tidak percaya diri karena takut salah. Melihat sikap siswa tersebut, jadi guru mengambil langkah untuk menunjuk siswa yang lain untuk memberi contoh jargon iklan persuasif. Aspek ini dilakukan oleh guru pada kegiatan inti pembelajaran, suasana pembelajaran lebih baik karena siswa selalu merespon pertanyaan guru mengenai materi pembelajaran.

3) Namai, penamaan pengalaman siswa akan menumbuhkan gairah belajar siswa, karena pada aspek ini siswa akan mendapatkan pengetahuan baru yang menarik. Setelah penerapan aspek ini, siswa tidak akan menyia-nyiakan setiap kegiatannya karena siswa akan merasa jika setiap kegiatannya baik di sekolah ataupun di luar sekolah (kehidupan sehari-hari) menjadi penting karena hal tersebut akan berkaitan dengan materi pembelajaran. Memberikan penjelasan dengan menggunakan bahasa santai yang mudah dipahami dan memberikan contoh materi yang berkenaan dengan kehidupan nyata siswa merupakan strategi pembelajaran yang dapat memudahkan siswa dalam menerima materi pembelajaran. Menggunakan bahasa yang mudah dipahami kepada siswa akan memberikan kesan pada siswa, pembelajaran yang berkesan akan membuat materi yang disampaikan akan bertahan lebih lama dalam memori siswa. Namun sayangnya saat pembahasan materi, bell pergantian pelajaran berbunyi menandakan pembelajaran harus diakhiri.

4) Demonstrasi, sebelum memulai pembelajaran, guru melakukan kegiatan refleksi guna untuk mengingat kembali mengenai materi pembelajaran yang telah dibahas pada pertemuan sebelumnya. Selain itu, bertujuan untuk menumbuhkan semangat belajar siswa dalam mengikuti proses pembelajaran. Setelah melakukan kegiatan refleksi, guru membentuk kelompok belajar yang telah ditentukan pada pertemuan sebelumnya. Pembagian kelompok belajar berdasarkan barisan tempat duduk siswa. Pada saat penerapan belajar kelompok, guru tetap mematuhi aturan kesehatan yang berkenaan dengan Covid-19 yaitu menjaga jarak antar siswa minimal 1 meter. Tiap kelompok diberi satu contoh teks persuasif yang berbeda, kemudian siswa membahas struktur dan kaidah kebahasaan teks persuasif yang terdapat pada teks persuasif tersebut. Aspek demonstrasi diterapkan pada kegiatan inti pembelajaran.

5) Ulangi, setelah kegiatan diskusi dilakukan, kemudian guru meminta masing-masing masing-masing perwakilan kelompok mempresentasikan hasil kerjanya di depan kelas dengan menggunakan bahasa sendiri. 
6) Rayakan, guru memberi pujian secara verbal yakni dengan memberi tepuk tangan ataupun mengacung salah satu jempolnya kepada siswa yang telah menyelesaikan tugasnya. Pada tahap ini guru tidak sempat memberikan evaluasi kepada siswa mengenai pembelajaran yang telah dilaksanakan karena alokasi waktu tidak cukup.

Berdasarkan hasil pengamatan pada siklus I menunjukkan bahwa guru telah melaksanakan pembelajaran sesuai dengan kriteria penilaian. Akan tetapi, masih terdapat kekurangan yaitui guru kurang tegas terhadap siswa yang kurang tertib saat pembelajaran serta guru kurang tegas dalam mengola alokasi waktu yang ditentukan. Sedangkan hasil observasi pada pertemuan kedua menunjukkan bahwa guru telah melaksanakan pembelajaran sesuai dengan kriteria penilaian. Akan tetapi, masih terdapat kekurangan yaitu guru terlalu cepat dan singkat memberi penjelasan terhadap materi sehingga menyebabkan siswa kesulitan dalam mengerjakan tugas (menulis) teks persuasif serta guru tidak melakukan evaluasi pembelajaran, karena alokasi waktu tidak mencukupi.

Penerapan model pembelajaran quantum pada tahap siklus I dalam proses pembelajaran memberi pengaruh yang baik terhadap hasil belajar siswa yaitu menulis teks persuasif. Adapun hasil nilai tes menulis teks persuasif siswa sebagai berikut.

Tabel 1. Daftar nilai tes menulis siswa pada tahap siklus I

\begin{tabular}{|c|c|c|c|c|c|c|c|c|c|c|c|}
\hline \multirow[b]{2}{*}{ No } & \multirow{2}{*}{$\begin{array}{l}\text { Nama } \\
\text { Siswa }\end{array}$} & \multicolumn{8}{|c|}{ Nilai } & \multirow[b]{2}{*}{ Ket } & \multirow[b]{2}{*}{ Indikator } \\
\hline & & $\begin{array}{c}\text { Siklus } \\
\text { I }\end{array}$ & KKM & 1 & 2 & 3 & 4 & 5 & 6 & & \\
\hline 1. & WNA & 79 & & 13 & 21 & 22 & 12 & 6 & 6 & Tuntas & Cukup \\
\hline 2. & $\mathrm{DN}$ & 84 & & 14 & 22 & 24 & 9 & 8 & 7 & Tuntas & Baik \\
\hline 3. & NAD & 64 & & 14 & 16 & 19 & 0 & 6 & 9 & $\begin{array}{l}\text { Tidak } \\
\text { Tuntas }\end{array}$ & Cukup \\
\hline 4. & MUS & 60 & 75 & 8 & 16 & 18 & 0 & 8 & 10 & $\begin{array}{l}\text { Tidak } \\
\text { Tuntas }\end{array}$ & Kurang \\
\hline 5. & OC & 59 & 10 & 9 & 19 & 17 & 5 & 5 & 4 & $\begin{array}{l}\text { Tidak } \\
\text { Tuntas }\end{array}$ & Kurang \\
\hline 6. & DW & 77 & & 11 & 20 & 18 & 13 & 8 & 7 & Tuntas & Baik \\
\hline 7. & SSB & 46 & & 8 & 16 & 15 & 0 & 4 & 4 & $\begin{array}{l}\text { Tidak } \\
\text { Tuntas }\end{array}$ & Kurang \\
\hline 8. & $\mathrm{KH}$ & 51 & & 8 & 15 & 15 & 5 & 5 & 3 & $\begin{array}{l}\text { Tidak } \\
\text { Tuntas }\end{array}$ & Kurang \\
\hline 9. & $\mathrm{RMN}$ & 59 & & 8 & 17 & 16 & 4 & 8 & 6 & $\begin{array}{l}\text { Tidak } \\
\text { Tuntas }\end{array}$ & Kurang \\
\hline 10. & SAN & 78 & & 14 & 22 & 17 & 9 & 8 & 8 & Tuntas & Cukup \\
\hline 11. & IML & 84 & & 15 & 20 & 23 & 12 & 9 & 5 & Tuntas & Cukup \\
\hline Jum & ah Nilai & & & & & & & 7 & & & \\
\hline
\end{tabular}


Nilai Rata-rata

Siswa yang Tuntas

Siswa yang Tidak Tuntas
67,3

6 Siswa

5 Siswa

Berdasarkan tabel di atas menunjukkan bahwa dari 11 siswa hanya 6 siswa yang tuntas dan ada 5 siswa yang tidak tuntas pada menulis teks persuasif. jika dipersentasekan, siswa yang tuntas ada 54,54\% sedangkan siswa yang tidak tuntas berjumlah 45,46\%. Data tersebut dapat disimpulkan bahwa setelah diterapkan model pembelajaran menulis teks persuasif, kemampuan menulis siswa mendapatkan kategori cukup, namun belum mencapai indikator keberhasilan.

\subsection{Refleksi Siklus I}

Pada tahap siklus I, nilai rata-rata menulis teks persuasif yakni 67,3. Nilai tersebut menunjukkan bahwa hasil belajar (menulis) teks persuasif siswa belum mencapai indikator keberhasilan yaitu 75 . Berdasarkan hasil tes yang diperoleh siswa pada siklus I menunjukkan bahwa masih diperlukan adanya siklus tambahan agar hasil belajar (menulis) seluruh siswa mencapai indikator keberhasilan. Untuk meningkatkan hasil belajar (menulis) teks persuasif dari tahap sebelumnya, adapun hal-hal yang dilakukan pada tahap siklus II yaitu sebagai berikut.

1) Agar siswa tertarik untuk mengikuti pembelajaran guru memberi materi kepada siswa menggunakan bahasa yang mudah dipahami

2) Memberikan bimbingan atau teguran kepada siswa menghambat proses pembelajaran.

3) Memperhatikan alokasi waktu yang telah ditentukan dalam setiap proses pembelajaran.

4) Guru memberi penjelasan secara santai dan rinci dengan menggunakan bahasa yang mudah dipahami, namun tetap memperhatikan alokasi waktu.

\section{Siklus II}

1) Tumbubkan, berdasarkan hasil pengamatan yang dilakukan penulis berdasarkan pertemuan pertama siklus II, pada saat memulai pembahasan materi, guru melakukan kegiatan tanya jawab kepada siswa tentang materi teks persuasif. Pada tahap ini seluruh siswa berantusias menunjuk tangan untuk menjawab pertanyaan. Sebagai pihak yang netral guru memberi apreseasi kepada siswa yang menjawab ataupun menanggapi pembelajaran yaitu dengan mengajak seluruh siswa untuk bertepuk tangan. Pada tahap siklus II ada perbedaan dalam menerapkan aspek yang dilakukan oleh guru. Pada tahap ini, guru memberi kesempatan bagi seluruh siswa untuk menjawab atau menangapi pembelajaran atau guru tidak lagi langsung menunjuk siswa untuk menjawab pertanyaan. Aspek ini tidak hanya diterapkan pada kegiatan awal pembelajaran saja, guru juga menerapkan aspek ini pada kegiatan yang lain ketika guru melihat semangat belajar siswa sudah mulai menurun.

2) Alami, untuk menumbuhkan semangat belajar siswa, guru mengaitkan sesuatu yang telah dialami siswa dengan materi pembelajaran, hal tersebut bertujuan untuk membuat suasana pembelajaran menjadi menyenangkan sehingga tujuan pembelajaran akan tercapai. Hal yang pertama kali dilakukan oleh guru adalah 
mencuri perhatian siswa yaitu dengan menyuruh siswa untuk mencontohkan iklan yang pernah dilihat oleh siswa. Kemudian guru meminta siswa untuk menampilkan salah satu produk iklan mie instan. Siswa memberi contoh nyanyian iklan. seluruh siswa yang lain terlihat ceria yaitu tertawa dan bertepuk tangan, hal itu menggambarkan bahwa siswa tersebut sangat menikmati pembelajaran. Setelah selesai bernyanyi, guru memberikan apreseasi kepada siswa tersebut. Kegiatan pembelajaran khususnya pada pembahasan materi tahap ini lebih mudah dari pertemuan-pertemuan sebelumnya, karena seluruh siswa berantusias untuk mengikuti pembelajaran. pada tahap ini, terjadinya interaksi antara guru dengan siswa maupun siswa dengan siswa.

3) Namai, dari iklan yang dicontoh salah siswa tadi, guru membagi jenis teks persuasif. Kemudian beberapa siswa yang lain menjawab. Guru memberi apreseasi kepada siswa yang merespon dengan memberi kata pujian "mantap, pintar sekali. Kalian memang is the best (mengacungkan kedua jempol) dan tepuk tangan dong tuk kita semua". Kemudian kegiatan selanjutnya ialah siswa dan guru melakukan evaluasi terhadap hasil menulis siswa pada tahap sebelumnya (siklus I pertemuan kedua) bersamaan dengan berdiskusi mengenai kaidah kebahasaan dan struktur teks persuasif sehingga siswa benar-benar paham bagaimana menyusun teks persuasif yang baik. Pada saat proses pembelajaran, terjadinya interaksi (timbal balik) antar siswa dengan siswa, maupun siswa dengan guru. Sebelum menutup pembelajaran guru memberikan pujian baik secara verbal di akhir kegiatan "Bagus untuk hari ini, kalian hebat semua. Ibu senang saat belajar semuanya aktif. Pertabankan ya! Ayo beri tepuk tangan untuk kita semua".

4) Demonstrasi, sebelum memulai pembelajaran, guru melakukan kegiatan apersepsi dengan memberikan pertanyaan mengenai materi yang telah dibahas guna untuk menumbuhkan semangat belajar siswa. Pada pertemuan sebelumnya siswa belajar secara berkelompok, maka pada pertemuan kedua siklus II ini guru membimbing siswa berdiskusi dengan teman sebangkunya untuk melakukan evaluasi mengenai hasil menulis teks persuasif siswa pada siklus I dengan memperhatikan kaidah kebahasaan dan stuktur teks persuasif sehingga siswa diharapkan mampu menulis teks persuasif dengan baik.

5) Ulangi, berdiskusi, guru memberi tugas kepada siswa yakni menulis teks persuasif berdasarkan iklan yang telah ditulis oleh siswa pada siklus I dengan memperhatikan struktur dan kaidah kebahasaan teks persuasif. pada saat proses pembelajaran baik sedang berdiskusi maupun sedang membuat tugas menulis teks persuasif berjalan dengan lancar, siswa sangat berantusias mengikuti proses pembelajaran. Alokasi waktu yang digunakan oleh siswa saat menulis teks persuasif pada pertemuan ini lebih cepat daripada pertemuan sebelumnya (pertemuan kedua pada siklus I).

6) Rayakan, sebelum menutup pembelajaran, guru menerapkan langkah quantum saat hendak mengakhiri pertemuan. Hal tersebut bertujuan agar pembelajaran yang telah dilaksanakan memberi kesan kepada siswa. Guru memberikan pujian baik secara verbal di akhir kegiatan.

Berdasarkan Hasil pengamatan pada siklus II menunjukkan bahwa guru telah melaksanakan pembelajaran sesuai dengan langkah-langkah pembelajaran yang telah disusun pada tahap evaluasi. Kegiatan observasi pada guru dilakukan dengan mengamati 
aktivitas guru mulai dari awal hingga akhir pembelajaran. Hasil observasi menunjukkan bahwa kegiatan pembelajaran sudah berjalan secara optimal sesuai dengan kriteria penilaian aktivitas guru. Hal tersebut dapat dilihat pada : 1) guru dapat mengatur alokasi waktu pembelajaran, sehingga waktu yang digunakan dalam proses pembelajaran lebih efektif. 2) guru selalu memberi kesempatan kepada siswa untuk bertanya, menjawab, dan menanggapi pembelajaran. 3) guru memberikan kesempatan pada siswa untuk menyampaikan kendala yang dihadapi oleh siswa dalam proses pembelajaran. 4) guru bersama siswa melaksanakan refleksi dan menyimpulkan kegiatan pembelajaran.

Penerapan model pembelajaran quantum pada tahap siklus II dalam proses pembelajaran memberi pengaruh yang baik terhadap hasil belajar siswa yaitu menulis teks persuasif. Hasil belajar (menulis teks persuasif) siswa tersebut diketahui karena pada saat pengamatan, penulis meminta daftar hasil nilai menulis teks persuasif siswa untuk melihat kemampuan menulis teks persuasif siswa kelas VIII A SMP Negeri 46 Bengkulu Utara setelah diterapkannya model pembelajaran quantum. Adapun hasil nilai tes menulis teks persuasif siswa sebagai berikut.

Tabel 2. Daftar nilai tes menulis teks persuasifpada tahap siklus II

\begin{tabular}{|c|c|c|c|c|c|c|c|c|c|c|c|}
\hline \multirow[b]{2}{*}{ No } & \multirow{2}{*}{$\begin{array}{l}\text { Nama } \\
\text { Siswa }\end{array}$} & \multicolumn{8}{|c|}{ Nilai } & \multirow[b]{2}{*}{ Ket } & \multirow[b]{2}{*}{ Indikator } \\
\hline & & $\begin{array}{c}\text { Siklus } \\
\text { II }\end{array}$ & KKM & 1 & 2 & 3 & 4 & 5 & 6 & & \\
\hline 1. & WNA & 82 & & 14 & 19 & 20 & 12 & 9 & 7 & Tuntas & Baik \\
\hline 2. & $\mathrm{DN}$ & 94 & & 15 & 25 & 25 & 12 & 10 & 7 & Tuntas & $\begin{array}{l}\text { Sangat } \\
\text { Baik }\end{array}$ \\
\hline 3. & NAD & 78 & & 13 & 23 & 18 & 11 & 7 & 5 & Tuntas & Cukup \\
\hline 4. & MUS & 82 & & 13 & 20 & 22 & 12 & 9 & 5 & Tuntas & Cukup \\
\hline 5. & OC & 76,5 & 75 & 12 & 20 & 19 & 12 & 9 & 4,5 & Tuntas & Cukup \\
\hline 6. & DW & 80 & & 13 & 20 & 23 & 11 & 8 & 5 & Tuntas & Cukup \\
\hline 7. & SSB & 77 & & 13 & 20 & 19 & 14 & 6 & 5 & Tuntas & Cukup \\
\hline 8. & $\mathrm{KH}$ & 79 & & 12 & 21 & 22 & 12 & 8 & 4 & Tuntas & Cukup \\
\hline 9. & $\mathrm{RMN}$ & 83 & & 11 & 23 & 25 & 11 & 7 & 6 & Tuntas & Cukup \\
\hline 10. & SAN & 82 & & 13 & 22 & 24 & 11 & 8 & 4 & Tuntas & Cukup \\
\hline 11. & IML & 95 & & 15 & 25 & 25 & 14 & 9 & 7 & Tuntas & $\begin{array}{l}\text { Sangat } \\
\text { Baik }\end{array}$ \\
\hline $\begin{array}{l}\text { Juml } \\
\text { Nilai }\end{array}$ & $\begin{array}{l}\text { ah Nilai } \\
\text { Rata-rata }\end{array}$ & & & & & & & $\begin{array}{l}84 \\
77\end{array}$ & & & \\
\hline
\end{tabular}


Berdasarkan hasil tes menulis teks persuasif di atas, terdapat 18,18\% yang mendapatkan kategori sangat baik, 9,1\% siswa yang mendapatkan kategori baik, dan $72,72 \%$ siswa yang mendapatkan kategori cukup. Berikut disajikan perbandingan hasil belajar (menulis) teks persuasif siswa VIII A SMP Negeri 46 Bengkulu Utara setelah diterapkan model pembelajaran quantum pada saat proses pembelajaran.

\begin{tabular}{|c|c|c|c|c|c|c|}
\hline \multirow{2}{*}{ No } & \multirow{2}{*}{ Nama Siswa } & \multicolumn{3}{|c|}{ Nilai } & \multirow{2}{*}{ Peningkatan } & \multirow{2}{*}{ Keterangan } \\
\hline & & KKM & Siklus I & Siklus II & & \\
\hline 1. & WNA & \multirow{11}{*}{75} & 79 & 82 & 3 & Meningkat \\
\hline 2. & $\mathrm{DN}$ & & 84 & 94 & 10 & Meningkat \\
\hline 3. & NAD & & 64 & 78 & 14 & Meningkat \\
\hline 4. & MUS & & 60 & 82 & 22 & Meningkat \\
\hline 5. & $\mathrm{OC}$ & & 59 & 76,5 & 17,5 & Meningkat \\
\hline 6. & DW & & 77 & 80 & 3 & Meningkat \\
\hline 7. & SSB & & 46 & 77 & 31 & Meningkat \\
\hline 8. & $\mathrm{KH}$ & & 51 & 79 & 28 & Meningkat \\
\hline 9. & $\mathrm{RMN}$ & & 59 & 83 & 24 & Meningkat \\
\hline 10. & SAN & & 78 & 82 & 4 & Meningkat \\
\hline 11. & IML & & 84 & 95 & 11 & Meningkat \\
\hline \multicolumn{3}{|c|}{ Jumlah Nilai } & 741 & 848,5 & 107,5 & Meningkat \\
\hline \multicolumn{3}{|c|}{ Nilai Rata-rata } & 67,3 & 77,13 & 9,83 & Meningkat \\
\hline \multicolumn{3}{|c|}{ Siswa yang Tuntas } & 6 & 11 Siswa & 5 & Meningkat \\
\hline \multicolumn{3}{|c|}{ Siswa yang Tidak Tuntas } & 5 & - & - & Meningkat \\
\hline
\end{tabular}

Pemerolehan hasil belajar (menulis) teks persuasif siswa kelas VIII A SMP Negeri 46 Bengkulu Utara pada tahap siklus II juga dapat dilihat melalui diagram Column. Berikut perbandingan pemerolehan hasil belajar (menulis) teks persuasif siswa dari tahap pratindakan hingga pelaksanaan siklus I dan siklus II diuraikan pada diagram berikut.

Diagram Perbandingan Hasil Menulis Siswa Tabap Siklus I dan Siklus II.

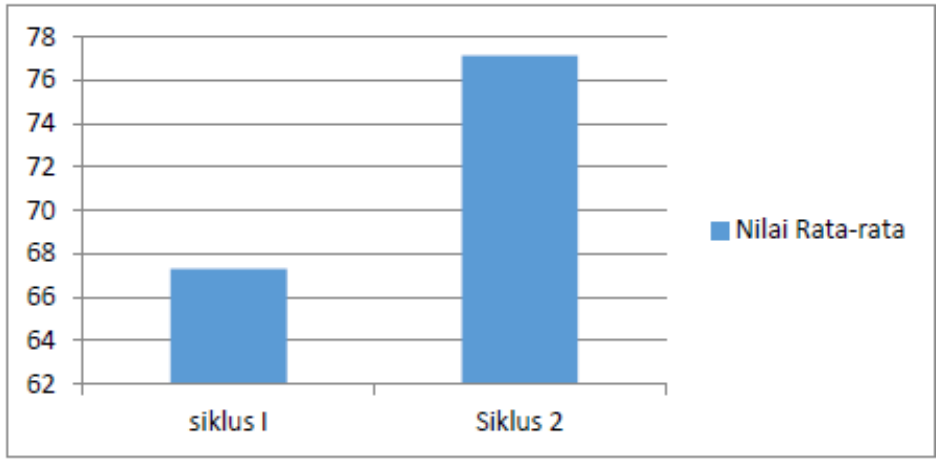




\subsection{Refleksi Siklus II}

Berdasarkan hasil pengamatan yang dilakukan penulis di kelas VIII A SMP Negeri 46 Bengkulu Utara pada tahap siklus II menunjukkan bahwa hasil belajar (menulis) teks persuasif siswa pada siklus II mengalami peningkatan dibanding dengan tahap sebelumnya. Hasil belajar (menulis) teks persuasif siswa nilai rata-rata siswa pada siklus I 67,3 menjadi 77,13 pada siklus II. Oleh karena itu, tindakan perbaikan dihentikan pada siklus II atau tidak dilanjutkan ke tahap atau siklus berikutnya. Keputusan tersebut dilakukan karena pada siklus II siswa kelas VIII A SMP Negeri 46 Bengkulu Utara memperoleh nilai rata-rata menulis teks persuasif 87,6 dan seluruh siswa telah mencapai kriteria ketuntasan minimal (KKM) atau lebih dari 75\%.

\section{Hasil Belajar Menulis Siswa Terhadap Penerapan Model Pembelajaran Quantum}

Salah satu kompetensi yang terdapat dalam mata pelajaran bahasa Indonesia di kelas VIII adalah keterampilan menulis teks persuasif yaitu KD 3.14 "Menelaah struktur dan kebahasaan teks persuasif yang berupa saran, ajakan, dan pertimbangan tentang berbagai permasalahan aktual (lingkungan hidup, kondisi sosial, keragaman sosial, dan sebagainya) yang didengar dan dibaca" dan 4.14 "Menyajikan teks persuasi (saran, ajakan, dan pertimbangan) secara tulis dan lisan dengan memperhatikan struktur, kebahasaan, atau aspek lisan". Kemampuan menulis siswa pada pembelajaran menulis teks persuasif siswa kelas VIII A SMP Negeri 46 Bengkulu Utara meningkat secara signifikan, hal tersebut dilihat dari hasil belajar (menulis) siswa dari siklus I hingga siklus II.

1) Pengenalan Isu, setelah diberi tindakan pada tahap siklus i, bagian pengantar atau pembuka teks persuasif sudah relevan terhadap isi teks walaupun adanya kesalahan penyebutan nama produk yaitu pada bagian kata "rinso cair" karena dari judul terlihat bahwa isi teks bukan menjelaskan tentang rinso cair tetapi tentang deterjen cair. Namun, hal tersebut memang sering terjadi karena kebanyakan masyarakat Indonesia sering menyebutkan nama produk adalah produk yang lebih dahulu dikenalnya. Bagian pembuka seharusnya disampaikan dengan disertai fakta-fakta dan menggunakan kalimat yang menarik sehingga membuat pembaca tertarik untuk membaca atau mengikuti teks yang ditulis hingga akhir. Namun, setelah diberi tindakan pada siklus II, kemampuan menulis teks persuasif siswa meningkat jauh lebih baik dibanding dengan menulis teks persuasif siswa pada tahap sebelumnya. Bagian pengantar karangan teks persuasif sudah relevan dengan topik, mengandung informasi sesuai dengan fakta, dan penyusunan kalimat yang digunakan lebih menarik sehingga mampu mempengaruhi pembaca untuk meanjutkan topik bacaan. Ciri penanda teks persuasif juga diuraikan secara jelas dan informatif.

2) rangkaian argumen, pada tahap siklus I dari segi pengekspresian gagasan dan kronologinya juga sudah mengalami peningkatan meskipun belum mencapai hasil yang diinginkan. Namun setelah diberi tindakan siklus II, aspek rangkaian argumen sudah meningkat jauh lebih baik. Kreativitas pengelolaan argumen yang dikemukakan pada karangan siswa sudah baik sehingga karangan siswa tersebut dapat menimbulkan kepercayaan bagi pembaca. gagasan disampaikan dikemukakan secara lancar, lengkap, dan terorganisir dengan baik.

3) pernyataan ajakan atau imbauan, pada tahap siklus I aspek ini meningkat menjadi kategori baik karena imbauan yang disampaikan hanya menarik dan menimbulkan kepercayaan 


\section{Else Pebrinda, M. Arifin, Ria Ariesta}

bagi pembaca. Kemudian diberi tindakan pada siklus II, aspek pernyataan ajakan atau imbauan sudah meningkat jauh lebih baik. ajakan atau imbauan yang dikemukakan pada teks persuasif siswa sudah menarik, menyampaikan ajakan ataup imbauan yang santun, dan menimbukan kepercayaan bagi pembaca.

4) penegasan kembali atau kesimpulan, pada tahap siklus I aspek ini meningkat menjadi kategori cukup karena imbauan yang disampaikan tidak menggunakan kata penutup (demikianlah/dengan demikian/oleh karena itu). Setelah diberi tindakan pada siklus II, aspek penegasan kembali atau kesimpulan sudah meningkat jauh lebih baik. kesimpulan teks yang ditulis pda teks siklus II pada teks persuasif siswa sudah sangat jelas dan kata penutup yang digunakan.

5) aspek kalimat, pada tahap siklus $\mathrm{i}$ aspek ini meningkat menjadi kategori baik karena keterkaiatan antarkalimat sudah jelas. Walaupun hasil yang diperoleh sudah baik, namun hal tersebut masih membutuhkan perbaikan guna untuk mendapatkan hasil yang maksimal. Setelah diberi tindakan pada siklus II, aspek kalimat sudah meningkat jauh lebih baik. Keterkaitan kalimat teks yang ditulis pada teks siklus II sangat jelas.

6) aspek ejaan dan tanda baca, pada tahap siklus I aspek ini meningkat menjadi kategori baik karena kesalahan dalam penggunaan ejaan dan tanda baca sudah ada pengurangan. Setelah diberi tindakan pada siklus II, aspek penggunaan ejaan dan tanda baca sudah meningkat jauh lebih baik dibanding dengan tahap sebelumnya. Penggunaan ejaan dan tanda baca sangat tepat dan hanya memiliki 2 kesalahan ejaan dan tanda baca.

\section{Pembahasan}

Berdasarkan hasil pengamatan, berbagai aktivitas pembelajaran antara guru guru dengan siswa dalam proses pembelajaran menulis teks persuasif dengan menerapkan model pembelajaran quantum pada tahap siklus I dan siklus II telah mengalami peningkatan. Kekurangan pembelajaran yang terdapat pada siklus I telah diperbaiki pada siklus II, sedangkan hal-hal positif tetap dipertahankan, sehingga proses pembelajaran (pelaksanaan tindakan) berjalan sesuai dengan yang inginkan. Saat proses pembelajaran, siswa memberikan tanggapan positif terhadap pembelajaran menulis teks persuasif dengan diterapkannya model pembelajaran quantum. Pembelajaran menulis ini mampu menciptakan suasana belajar yang menarik dan menyenangkan sehingga siswa mengikuti proses pembelajaran dengan baik. Siswa mau memperhatikan pembelajaran yang disampaikan guru dengan penuh perhatian. Saat pembelajaran siswa terlihat sangat menikmati proses pembelajaran sehingga pelaksanaan penelitian tindakan kelas ini berjalan dengan lancar. Pelaksanaan tindakan penelitian ini dihentikan pada tahap siklus II karena seluruh aspek pengamatan penelitian dalam menerapkan model pembelajaran quantum saat proses pembelajaran telah dilaksanakan sesuai dengan rencana dan telah mendapatkan hasil yang maksimal.

Pada tahap siklus I semua aspek dan kriteria dalam menulis teks persuasif kemampuan menulis siswa masih dalam kategori cukup. Pada aspek Pengenalan Isu, pengantar atau penyampaian tentang masalah yang diangkat dalam teks jelas. Pada aspek rangkaian argumen sudah terdapat beberapa (satu atau dua) pendapat penulis terkait dengan isu/masalah yang diangkat disertai dengan fakta. Pada aspek pernyataan ajakan/imbauanyang disampaikan hanya menarik dan menimbulkan kepercayaan bagi pembaca. Pada aspek penegasan kembali/kesimpulan cukup jelas dan ditandai dengan adanya kata penutup (demikianlah/dengan demikian/oleh karena itu). Pada aspek 
kalimat, keterkaitan antarkalimat sudah jelas. Terakhir adalah aspek ejaan dan tanda baca, penggunaan ejaan dan tanda baca cukup tepat (kesalahan ejaan dan tanda baca 5-6).

Pada tahap siklus II semua aspek dan kriteria dalam menulis teks persuasif mengalami peningkatan yang signifikan. Pada aspek pengenalan isu, pengantar atau penyampaian tentang masalah yang diangkat dalam teks sangat jelas. Pada aspek rangkaian argumen Sudah terdapat sejumlah pendapat penulis terkait dengan isu/masalah yang diangkat disertai dengan fakta atau bukti. Pada aspek pernyataan ajakan/mmbauan yang disampaikan memenuhi menarik, santun, dan menimbulkan kepercayaan bagi pembaca. Pada aspek penegasan kembali/kesimpulan sangat jelas dan ditandai dengan adanya kata penutup (demikianlah/dengan demikian/oleh karena itu). Pada aspek kalimat, keterkaitan antarkalimat sangat jelas. Terakhir adalah aspek ejaan dan tanda baca, penggunaan ejaan dan tanda baca sangat tepat (hanya ada 1-2 kesalahan ejaan dan tanda baca).

Pada tahap siklus II, hasil penelitian baik dari segi penerapan model pembelajaran quantum saat proses pembelajaran menulis teks persuasif maupun hasil belajar (menulis) teks persuasif siswa pada kelas VIII A SMP Negeri 46 Bengkulu Utara mengalami peningkatan yang sangat memuaskan atau kategori sangat baik.

Dari uraian di atas dapat disimpukan bahwa model pembelajaran quantum sangat cocok untuk diterapkan saat proses pembelajaran karena pembelajaran quantum adalah pengubahan cara belajar menjadi menyenangkan dengan seluruh nuansa. Pengubahan suasana pembelajaran menjadi menyenangkan memberi dampak positif terhadap hasil pembelajaran siswa karena minat belajar siswa menjadi meningkat.

\section{Keterbatasan Penelitian}

Penelitian tindakan kelas untuk meningkatkan kemampuan menulis teks persuasif siswa kelas VIII A SMP Negeri 46 Bengkulu Utara dengan menerapkan model pembelajaran quantum dalam proses pembelajaran. Pelaksanaan tindakan ini didasarkan pada hasil diskusi antara penulis dengan guru yang menyatakan bahwa sudah ada peningkatan baik dari segi proses pembelajaran maupun hasil belajar (menulis) teks persuasif siswa.

Peningkatan yang terjadi sudah memenuhi indikator keberhasilan tindakan. Selain itu, peneitian tindakan kelas ini dihentikan karena terbatasnya jadwal peneitian dan banyaknya materi pembelajaran yang beum diajarkan oleh guru. Selain itu, Penelitian ini juga terdapat kendala lain yakni minimnya waktu pelaksanaan pembelajaran disebabkan karena adanya peraturan pemerintah mengenai pelaksanaan pembelajaran pada saat terjadinya Covid-19 sehingga menyebabkan peaksanaan pembelajaran dilakukan dengan pergerakan yang terlalu cepat. Tetapi semua itu bisa diatasi oleh siswa dan siswa berhasil menyelesaikan tugas menulis teks persuasif dengan baik.

\section{PENUTUP}

Berdasarkan pelaksanaan tindakan penelitian yang telah dilaksanakan serta pembahasan pada bab sebelumnya dapat disimpulkan bahwa penerapan model pembelajaran quantum pada pembelajaran menulis teks persuasif siswa kelas VIII A SMP Negeri 46 Bengkulu Utara dapat meningkatkan kemampuan menulis siswa. Hal tersebut dapat dilihat dari peningkatan yang terjadi pada hasil belajar (menulis) siswa setiap siklusnya yakni nilai ratarata menulis teks persuasif pada siklus I 76,5 atau 81,8\% siswa yang tuntas dan meningkat 


\section{Else Pebrinda, M. Arifin, Ria Ariesta}

pada siklus II 87,6 dan seluruh siswa memperoleh hasil yang maksimal atau tuntas. Penerapan model pembelajaran quantum dalam proses pembelajaran secara keseluruhan berlangsung dengan baik, menarik, dan menyenangkan. Langkah-langkah penerapan model pembelajaran quantum antara lain Tumbubkan, Alami, Namai, Demonstrasi, Ulangi, dan Rayakan. Langkah-langkah tersebut dapat meningkatkan minat belajar siswa untuk mengikuti proses pembelajaran. pelaksanaan penelitian dilaksanakan selama 2 siklus, setiap siklus terdiri dari 2 kali pertemuan, pertemuan pertama langkah yang diterapkan ialah Tumbubkan, Alami, dan Namai. Sedangkan pada pertemuan kedua, langkah yang diterapkan ialah Demonstrasi, Ulangi, dan Rayakan.

Jurnal ini dapat diselesaikan berkat dukungan, doa, serta bantuan dari berbagai pihak. Oleh karena itu, penulis mengucapkan terima kasih kepada semua pihak yang telah memberi kontribusi dalam menyelesaikan jurnal ini. Secara khusus pada kesempatan ini penulis menyampaikan terima kasih kepada Drs. M. Arifin, M.Pd. selaku Pembimbing Utama, Dr. Ria Ariesta, M.Pd. selaku Pembimbing Pendamping, Fitra Youpika, M.Pd. Pembimbing Jurnal, serta seluruh Mahasiswa Pendidikan Bahasa Indonesia FKIP Universitas Bengkulu Angkatan 2016.

\section{DAFTAR RUJUKAN}

Arifah, N. (2015). Peningkatan Keterampilan Menulis Persuasi Melalui Model Think Pair and Share Berbantuan Media Visual pada Siswa Kelas IV SDN Sekaran 02 Semarang . UNNES, 2. diunduh tanggal 02 September 2020, pukul 07.30 WIB.

Arifina, Basiska Winda, Basaria Winda. (2015). Pengarub Penerapan Model Pembelajaran Quantum Teaching Terbadap Keterampilan Menulis Puisi Siswa Kelas III. Jurnal 1 [111]. diunduh tanggal 22 Agustus 2020, pukul 09.30 WIB.

Dalman. (2012). Keterampilan Menulis. Jakarta: PT Grafindo Persada.

DePorter, Bobbi. (2010). Quantum Teaching. Bandung: PT Mizan Pustaka.

Huberman, S. (2011). Analisis Data Penelitian Kualitatif Model Miles dan Huberman. Pasca UMS. diunduh tanggal 18 Agustus 2020, pukul 20.00 WIB.

Kosasih, E. (2017). Bahasa Indonesia kelas VIII. Jakarta: Pusat Kurikulum dan Perbukuan, Balitbang, Kemendikbud.

Kurniawan, $\quad$ R. (2015, $10 \quad 30)$ Retrieved from https://rohadicgbs.wordpress.com/2015/10/30/apa-itu-quantum-learningpengertian-teori-dan-tujuan/. diunduh tanggal 18 Agustus 2020, pukul 07.30 WIB. 